\author{
Jane Mattisson Ekstam \\ Østfold University College
}

DOI: http://dx.doi.org/10.5617/adno.6093

\title{
Metacognition and Reader Response: the use of reading logs in the envisionment-building classroom
}

\begin{abstract}
My article discusses the advantages of reading logs in teacher training programmes, and more specifically in connection with teaching literature and the Reader Response theory. This is an effective pedagogical method for enabling pre-service teachers to explore what they can discover in a literary text, and assess how deeply they can read. The study is based on a course in British culture and literature for student teachers at the middle- and secondaryschool levels. It was given at a university college in Norway in the autumn term 2016. The students were in their second and third years and had completed a short, introductory course in literary analysis the previous year.

I analyse the students' reading logs from an "envisionment" perspective. Envisionment refers to the picture of the world that one has at a particular point in time and how it affects reading comprehension. Judith Langer argues that there are five reading stances. The students' reading- log comments have been categorized according to these five levels. This makes it possible to ascertain if, and to what extent, the students' reading has become deeper. The students themselves can also see how their comments have changed. Such a process promotes metacognitive thinking. In my follow-up research, I shall develop the project by giving the students more time to discuss one another's reading logs in class, and reflect on how the method could be applied in the school classroom. The increased self-reflection will benefit both the students themselves and their future pupils.
\end{abstract}

Keywords: reading, reading logs, metacognition, Judith Langer, Reader Response 


\section{Metakognition och "Reader Response”: läslogböcker i Judith Langers “envisionment” klassrum}

\section{Sammanfattning}

Min artikel diskuterar fördelarna med att använda läslogböcker i lärarutbildning, och mer specifikt i samband med litteraturundvisning där "Reader Response" är huvudmetod. Detta är en effektiv pedagogisk metod för att uppmuntra lärarkandidater att fundera på hur de läser, vad de kan se i en litterär text, och hur djupt de kan läsa. Studiet baseras på en kurs i brittisk kultur och litteratur för blivande mellanstadie- och högstadielärare som gavs vid en mindre högskola i Norge höstterminen 2016. Studenterna var andra, respektive tredje årsstudenter och hade genomgått en kort introduktionskurs $i$ litteraturanalys året innan.

Jag analsyerar studenternas läslogböcker utifrån Judith Langers teori om "envisionment", dvs. den världsbild som man har vid ett specifikt tillfälle och hur denna påverkar läsförståelse. Langer menar att det finns fem möjliga läsnivåer. Läslogböckerna har lästs utifrån dessa fem nivåer. På det sättet kan läraren se om och i så fall i vilken mån studenterna har utvecklat sin läsning samt om denna har blivit djupare. Minst lika viktigt är att studenterna kan se hur djupet på sina kommentarer har ändrats. Detta främjar en metakognitivistik syn på uppgifter. I nästa forskningsprojekt vill jag utveckla metoden för att ge studenterna större möjlighet att läsa och diskutera sina läslogböcker $i$ klassrummet, ge varandra kritik, och fundera på hur metoden kan tillämpas för deras elever. Detta möjliggör en ökad grad självreflektion som gagnar både studenterna och deras framtida elever.

Nyckelord: läsning, läslogböcker, metakognition, Judith Langer, Reader Response

\section{Introduction}

This article discusses the advantages of reading logs in teacher training programmes, and more specifically in connection with teaching literature and the Reader Response theory. It focuses primarily on what the teacher can learn from the logs about her students' ability to read, understand and reflect on a fictional text; it also discusses how the students themselves can learn from their comments. Reading fiction is all about meaning making. While an important feature of teacher training education today is the promotion of critical thinking, several studies conducted recently in Scandinavia indicate that little attention has been paid to the development of meta-skills for dealing with texts critically (Kjelen, 2013; Krogh, Penne \& Ulfgard, 2012; Rødnes, 2014; Skarstein, 2013). 
A pre-condition for critical thinking is metacognition or self-regulated learning, i.e. "knowledge and cognition about cognitive phenomena" through "cognitive monitoring” (Flavell, 1985, p. 906). Such monitoring incorporates metacognitive knowledge, i.e. combinations of information focused on three knowledge variables: self, task and strategies, along with metacognitive experiences, that is to say, "items of metacognitive knowledge that have entered consciousness" (Flavell, 1985, p. 908). These items enable the student to understand where he or she is in the task in hand, which, in the case discussed here comprises keeping a reading log based on J. K. Rowling's Harry Potter and the Philosopher's Stone (1997). I demonstrate that metacognitive knowledge and experiences allow students to become more strategic and thoughtful learners.

The combination of metacognitive knowledge and experiences has the potential to promote skilled reading. To become a skilled reader it is necessary to pass through three stages: "preparing to read", "constructing meaning while reading", and "reviewing and reflecting on reading" (Griffith \& Ruan, 2005, p. 7). In the "preparing to read" stage, the goals of reading become clear, and the reader activates prior knowledge. In the "constructing meaning while reading" stage, the reader identifies the main ideas, "predicts, makes inferences, interprets and evaluates, integrates ideas into a coherent representation of the text, [and] monitors understanding" (Griffith \& Ruan, 2005, p. 7). In the "reviewing and reflecting on reading" stage, the reader asks him-/herself questions for understanding, invokes strategies for reviewing and understanding the text, and summarizes and processes the text in accordance with his/her established reading goals. To become skilled readers, students require knowledge of their own cognitive resources and the aims of the reading task. It is important that such knowledge and aims are mutually compatible.

This requires a level of self-awareness, which, in turn, entails knowing what kind of a learner one is. In her research on learning logs, Barclay, for example, has identified four kinds of learners: activists, reflectors, theorists, and pragmatists. Activists "involve themselves fully and thrive on new experiences" (1996, p. 28). Reflectors keep a distance to experiences as they reflect on them. Theorists adjust and "integrate observations into sound theories" (1996, p. 28), and pragmatists are anxious to experiment with ideas, theories and techniques in order to test if they function in practice.

Pre-service teachers should be aware of different learning styles and encouraged to think of reading in the classroom not merely as a comprehension exercise but also as an opportunity for students to think on their feet. To do this, they must be aware of their knowledge - social, intellectual and experiential and how this evolves as they read. This complex process is individual and does not follow a strict pattern. As teachers of pre-service teachers, we must prepare our students to "move outside supposed certainties into the less secure, more tentative and problematic arena of complexities, instability and value conflict" (Smyth, 1989, p. 195). Pre-service teachers must thus be adaptive, and "in 
metacognitive control of their work” (Duffy, 2005, p. 306). As a result, and in the spirit of Bruner (1990), students must learn to see literature as a way

not only to see [themselves], but also to re-create [themselves] . . . . In its best sense, literature is both intellectually provocative and humanizing, allowing us to use various points of view to examine thoughts, beliefs, and actions. (Langer, 2011, p. 5)

From this perspective, it is clear that it is necessary to move beyond literal text comprehension and create what McDaniel calls "critical literacy", which "transcends conventional notions of reading and writing to incorporate critical thinking, questioning, and transformation of self or one’s world” (2004, p. 474). Judith Langer's notion of "literate thinking" is very similar to this view but in addition, it highlights the importance of students understanding that literature is not only a text but also a specific way of thinking. As Langer argues, literature requires "intelligent and literate thought that brings with it particular reasoning and problem-solving strategies” (2011, p. 2). Literate thought, she claims, enables students to think and re-think how they understand

texts, themselves, and the world. It gives importance to individuals and the oral and written texts they create and encounter. It calls upon and fosters the kind of language and thought that mark good and sharp thinking. (Langer, 2011, p. 3)

\section{Literature review}

The primary focus in research on reading and the teaching of reading has been, and still is, on the acquisition of specific skills and strategies for comprehension rather than on finding new methods for understanding and adapting to the challenges of a rapidly changing world. The present-day demand for instant access to information, for example, tends to take precedence over careful reflection and deep reading. Preparing Teachers for a Changing World: What Teachers Should Learn and Be Able to Do (Darling-Hammond et al., 2007), for example, argues that "teachers' abilities are especially crucial contributions to students' learning” (p. 2). While the authors claim that students must understand increasingly complex material, there is little focus on reading as such, and no separate chapter devoted to the importance of reading either for basic comprehension or for deeper understanding.

Reading theorists have traditionally focused on top-down and bottom-up skills and strategies for the successful understanding of a text (Carrell et al., 1988; Aebersold \& Field, 1997; Eskey \& Grabe, 1988). Such comprehension is measured in terms of how much "correct" information the reader can gain from the text rather than on promoting thought or contributing to the formation of the reader's worldview. Numerous instruction books for teachers of reading in primary and secondary schools, for example, have appeared on the market in the 
last few years (McKenna, and Dougherty Stahl, Assessment for Reading Instruction, 2015; Gambrell, Morrow \& Shanahan, eds. Best Practices in Literary Instruction, 2015). These books prioritise comprehension, and the importance of extracting "the correct" facts from the text; they do little to promote thoughtful reading or influence the reader's worldview.

This is not, of course, to denigrate in any way the importance of cognitive effort in the reading process (see, for example, Bazerman, 1985). There must, however, be a greater emphasis on the metacognitive processing of the text that is "procedural, purposeful, effortful, willful, essential, and facilitative in nature"; "the reader must purposefully or intentionally or willfully invoke strategies" (Alexander \& Jetton, 2000, p. 295). Such strategies should ideally enable the reader to develop personal meaning and understanding and to see the world in a new light. These strategies can, of course, in part be acquired with the aid of textbooks and instruction in the classroom, particularly in the early stages of education, but they must be increasingly honed and personalised as the reader becomes more proficient and more aware of his/her relationship to texts. This is particularly important today, where students gain instant access to massive amounts of information on the Internet. This information must be reflected on and processed. With the aid of metacognitive strategies, the reader is able to control as well as monitor and evaluate the reading process (Pressley, 2000; Pressley, Brown, El-Dinary \& Afflerbach, 1995). As this article argues, a particularly effective way of monitoring one's reading strategies is to compile a reading log.

Interestingly, the individual and social dimensions of reading, and particularly, of reading literary texts, are attracting increasing attention. This is especially the case with respect to identifying the ideology of a text as part of the process of either identifying with, or becoming resistant to the content (Spolsky, 1989; Wallace, 1992). This is particularly important in literature, which immerses the reader in a new world from which he/she will gain new insights and create new meaning.

Part of this process is exploring the intertextual and intercultural relationships between different types of texts (Corbett, 2003; Montgomery, Durant, Fabb, Furniss \& Mills, 2000). Literature, when read with self-reflection, "opens up, calls upon, stimulates, and uses areas of the mind, from imagination to emotion, from pleasure to pain,” (McRae, 1991, p. 3). This requires guidance and practice, and presupposes that the teacher both understands and appreciates the special powers of literature.

At the same time, it is also important to highlight the significance of students' own responses in the reading process, and particularly the relationship between their own experiences both inside and outside of texts and how these impact on how they understand literary texts. Reader Response demonstrates that readers imbue texts with meaning; texts do not have meaning in themselves (Rosenblatt, 1983). 
A novel or poem remains merely inkspots on a paper until a reader transforms them into a set of meaningful symbols. The literary work exists in the live circuit set up between reader and text: the reader infuses intellectual and emotional meanings into the pattern of verbal symbols, and those symbols channel his thoughts and feelings. Out of this complex process emerges a more or less organized imaginative experience. (p. 25)

Reader Response theory assumes that there is a transactional or reciprocal relationship between the reader and the text. The reader's emotions, experiences and whatever he or she brings to the text play the most prominent role in the interpretative process. The Reader Response approach to language teaching has a number of advantages: it leads, for example, to autonomous learning, fosters classroom discussions and encourages students to express their opinions as well as listen to those of others. Literary texts have particular advantages in the language classroom: they encourage multiple interpretations, stimulating discussion, and they

are non-trivial in the sense that they deal with matters which concerned the writer enough to make him or her write about them. In this they are unlike many other forms of language teaching inputs, which frequently trivialize experience in the service of pedagogy. This "genuine feel" of literary texts is a powerful motivator, especially when allied to the fact that literary texts so often touch on themes to which learners can bring a personal response from their own experience. (Duff and Maley, 1990, p. 17)

As Bauso points out, it is an "old commonsense view that a good reader reads with pencil in hand ... if students do writing in close conjunction with reading, then they will be more active and therefore more successful readers" (1988, p. 256). While students today choose to write their reading logs on the computer, they are still encouraged to mark passages in the literary text itself so that they can return to these in classroom discussions. Bauso points out that an additional advantage of the reading log is that it does not make undue demands on the teacher's time.

From the metacognitive point of view, reading logs also have the potential to enable students to carry out a form of self-diagnosis as they categorise their comments according to Langer's five stances. Such a process will not only enable them to deepen their level of reading but also encourage them to consider how their own experience of reading can be utilized in their own teaching. Even without identifying stances, and as Lyutaya argues, reading logs enable students to "reflect on their discoveries, and make connections between what they know and what they are learning" (2011, p. 29). This is not only beneficial to themselves but also in their teaching.

The reading log is a particularly efficient means of promoting interaction with texts, and furthering understanding of, and reflection on intertextual and cultural relationships in texts by enabling the reader to enter the secondary 
world, of which more below. "Most students use journals to move beyond the knowledge and skills available through normal classroom activities" (Hiemstra, 2001, p. 20). A few critics have argued that the advantages of reading logs for second language learners are particularly great although not all critics are unanimous on this point (see, for example, Maria de la Ruz Reyes, "A Process Approach to Literacy Using Dialogue Journals and Literature Logs with Second Language Learners"). Reyes claims that because L2 learners do not always have sufficiently well-developed language skills in English, literature logs may inhibit the construction of meaning and lead to a poor self-image. With respect to the present study, while students did occasionally write in their logs that they were bored with the task and sometimes felt that writing a log detracted from enjoyment of the text, such comments were few and only given by two students.

Researchers are generally overwhelmingly enthusiastic about the use of reading logs in the classroom. Carlisle is a good example. He claims that, "While reading logs are already used in L1 [native speaker] literature teaching ... the activity is particularly appropriate for L2 [second language] use, since it stimulates foreign language readers to go beyond the first barrier of semantic understanding and to move towards critical appreciation” (Carlisle, 2000, p. 12). This, in turn, normally increases our pleasure in reading, as evidenced by among others Nancy Wilson (1989, p. 62). If our student teachers are to encourage their pupils to read, and to read critically, it is necessary to enjoy the reading experience. How this is achieved is discussed below, in relation to Langer's "envisionment" theory. Envisionment, or the gradual development of meaning, is fundamental to our understanding of the value of reading, and most especially, of deep reading.

\section{"Envisionment”}

The focus both in Langer and in the present article is on the experience of reading itself, what Anthony Carlisle terms the "aesthetic transaction". Preservice teachers must understand that in reading literature we enter what J. R. R. Tolkien (1997) calls the "secondary world", which is not the same as the one in which the reader lives. A reader inside a secondary world engages in four separate processes, all of which are elements of response to literature (Benton and Fox, 1985, pp. 2-18): anticipating/retrospecting, picturing, interacting, and evaluating. In the anticipating/retrospecting process, the reader guesses what is going to happen next, what events led to the present situation, and what will happen at the end of the book. In the picturing process, the reader forms images in his/her mind, imagining, for example, a particular scene. In the interacting process, the reader forms opinions about a character's personality and actions or particular situations or events. In the evaluating process, the reader considers the writer's technique and skill. Literature needs to be talked about. Reading logs 
such as those considered below form a useful foundation for discussion; it is, after all, as Carlisle points out, "our differing viewpoints that make the conversation interesting” (2000, p. 14). From a metacognitive perspective, the conversation takes place on two levels: with oneself (what do I understand by this observation? How have my remarks about the text changed and evolved through the reading log?), and with others: in the present case, with fellow students and the teacher. While discussion time in class was limited, students were encouraged to think about how their identity as teachers is developed through reading and listening to fellow students' thoughts on their novel Harry Potter; this is an important part of the teacher identity discourses that are so important in negotiating personal and professional spaces (see Alsup, 2006).

Our understanding of literature relies on and reflects "envisionment", i.e. "the world of understanding a particular person has at a given point in time" (Langer, 2011, p. 10; see Langer's video on Youtube: https://www.youtube .com/watch?v=GtI2rRfPy7o). A reader's envisionment is not static but passes through stages or "stances". Langer's stances are more detailed than Benton and Fox's four processes of reading discussed above. They do not necessarily follow a linear pattern but are usually on a continuum, where the reader may jump backwards and forwards. This proved to be the case with the students whose reading logs are discussed below. Ideally, readers, according to Langer, will reach stance three or, preferably, four. Students rarely reach stance five. While research has been conducted on Langer's concept of envisionment and its relations to teaching reading in the classroom, and particularly the school classroom (see, for example, Mary Ingemansson, 2016), her concept and the five stances have not yet, to the present writer's knowledge, been specifically related to reading logs and their application within student-teacher education.

Briefly, the stances can be summarized as follows: stance one incorporates "Being outside and stepping into an envisionment" (Langer, 2011, p. 17). At this stage, we try to form an understanding of what the text is about, picking up clues and trying to make sense of the text. Our understanding is superficial at this stage, and is based on our own knowledge and experiences. We focus on characters, plot, setting and situation, and how they interrelate. Our initial understanding of the text can prove to be inaccurate, making it necessary to modify our envisionment.

Langer defines stance two as "Being inside and moving through an envisionment". This, as she explains, is the most frequently entered stance. Here we use the social context of our reading to produce ideas and stimulate our thinking. We use new information to go beyond our understanding of the text, asking questions relating to "motives, feelings, causes, interrelationships, and implications" (Langer, 2011, p. 18). Meaning stimulates further meaning. We use our knowledge "of the text, ourselves, others, life, and the world" (Langer, 2011, p. 18) to make connections between our different kinds of knowledge and to modify as well as adjust our initial understanding of the text. 
The third stance, "Stepping out and rethinking what you know", is different to the previous two in that instead of using our knowledge and experience to understand the text world, we use it to augment our own knowledge and experiences. We step back and re-think what we know. There is a reciprocity between the fictive and the real world: "The envisionment illuminates (and influences) life, and life illuminates (and influences) the envisionment” (Langer, 2011, p. 19). It is this stance that helps us to sort out our own lives through literature, revealing our possible as well as our present selves.

In stance four, "Stepping out and objectifying the experience" (p. 20), we distance ourselves from the envisionment that we have formed, reflecting on, analysing and judging it as well as relating it to other works and experiences. At this stage, it can be useful to study the structure of the text, literary elements and allusions. We become critics who can identify and consider the implications of differences between our own and the author's sense of the world. We may, for example, look at references to or insinuations of conflict and power and compare with other works of literature. This stance requires knowledge of the nature of literary texts and the ability to compare with other literary texts. It thus presupposes proper training in understanding literature.

The final stance, stance five, "Leaving an envisionment and going beyond" (pp. 21-22), is much rarer than the previous stances. This is because it is a particularly demanding stage that requires us to move away from our earlier envisionments and into an entirely new one. We move beyond our earlier insights and apply what we have learned to new works of literature and new experiences. As Table Four in my appendix demonstrates, there were only eight instances of stance five in my students' logs, and these appeared in only three out of the twenty-two log-books.

Langer does not recommend that the five stances be taught separately: they are interrelated and not always clearly separable. It is useful to introduce the notion of stances to students in order to help them become more aware of their level of reading. I chose not do this in the study discussed here because it was my first time teaching Norwegian students and I was anxious not to add to the students' workload without first checking that they could cope with additional tasks. Having taught the course once, I now know that I can (and will) introduce the notion of stances to the students following the same course this year, i.e. 2017, of which more at the end of the present article.

\section{Research question}

The fundamental question posed in this text is "to what extent can keeping a reading log enhance students' ability to read and reflect on a fictional text at different levels?" The focus is on what the teacher can learn about her students' ability to read at various levels. At the same time, this has the potential for 
improving the teacher's ability to assess reading levels. As my conclusion indicates, I am planning a continuation of the present project in the form of a study of the students' assessment of a) their own entries and b) those of their fellow students.

\section{Method}

My study examines the students' reading logs in terms of their advantages for the students themselves and for teacher training programmes. By assessing my students' reading logs in accordance with Langer's stances, I was able to determine how deeply the students read their novel. The stances were highlighted in the logs, which were re-read three times in order to double check my initial assessments. My assessment of the stances has been checked by a senior colleague in literature. All statistics have been checked by an experienced mathematician and statistician. Where chosen examples could be regarded as ambiguous or incomplete, they were excluded from the investigation and are thus not included in the totals displayed in the table of results below.

\section{Material}

As already established, the literary text that forms the basis of the present discussion is J. K. Rowling's Harry Potter and the Philosopher's Stone, first published in 1997. The novel has been translated into at least sixty-seven different languages and is the first in a series of seven novels. Judging from its enormous popularity worldwide, it is clear that Harry Potter will become a classic and feature regularly in school and college of education syllabi.

Harry Potter and the Philosopher's Stone is one of four novels included in the British Culture and Literature course that is compulsory for the students in the 5-10 teacher training programme and optional for the students following the 1-7 programme. Not only is the novel extremely popular, it also constitutes "an exceptionally good example of how historical themes and topics can inform fictional storytelling, even when its setting is contemporary” (Kern, 2003, p. 14). The series is "a powerful, cross-cultural representation of contemporary anxieties about childhood power (both political and personal), knowledge and education” (Belcher \& Stephenson, 2011, p. 3). In addition, Rowling also "develops a moral system that updates ethical principles with a very rich history of their own" (Kern, 2003, p. 14). This is not the place to go into the relationship between fiction and ethics but readers are recommended to consult On the Turn. The Ethics of Fiction in Contemporary Narrative in English (Arizti \& MartinézFalquina (Eds.). 2002). 


\section{Participants}

The present study took place in the autumn term 2016, and involved twenty-two second-year pre-service teachers, eighteen of whom will be teaching levels 5-10 (11-16 year-old pupils) and four, who will be teaching 1-7 (7-11 year-old pupils). The average age of the students was 22. There were nine male and thirteen female students. The two student groups were taught together and asked to read, among other novels, J. K. Rowling's Harry Potter and the Philosopher's Stone.

\section{Procedure}

The students were requested to record questions, memories, guesses, reflections, comparisons, thoughts and feelings, comments and connections and to make an outline of each chapter of Harry Potter (the full instructions are to be found in the final appendix, after the four tables of results). Despite the instructions, three students produced reading logs that contained only basic descriptions and very short summaries of the main events in the chapters; there were no personal Reader Response comments. These three logs are thus excluded from the following discussion of results.

In addition, the students were asked to sign a consent form agreeing to allow me to use their entries in their entirety but anonymously. The logbooks were given a number to ensure anonymity. In collating my results, I read through the logs three times for each person; the first time, to gain a general impression, the second, to mark comments specifically related to Langer's stances; and the third, to identify further examples of Langer's stances missed in the first two readings, as well as to add my own comments. As previously stated, my assessment of the stances and their diagrammatic representation (see Figure 1) have been checked by a senior colleague in literature. The statistics have been checked by an experienced mathematician and statistician.

I classified the responses in four tables presenting the results of three groups of chapters: 1-5, 6-11 and 12-17 (see tables 1-4 in the Appendix; table 4 provides an overall view of the results). The tables register the number of times each level of response occurs in each chapter in order to a) establish patterns of frequency in levels of stance, b) ascertain if stances 1 and 2 occur, as one would expect, particularly frequently in the early chapters, and c) how often stances four and five are reached, and in which chapters. The criteria for each stance were used to assess the students' comments and reflections on the novel.

As already established, entries that were unclear or written in such poor English that the meaning was not entirely clear are not included in the analysis below. Where quotations from the reading logs are included, they are presented 
in their original form, i.e. without any changes to language or style. The results of each of the three sets of chapters are presented below.

\section{Data analysis}

It is surprising that no similar study, to the author's knowledge, has been conducted on reading stances and their inclusion in reading logs. Langer's envisionment theory offers apt categorizations of the types of comments often found in reading logs.

In considering the results of the present study, it is important to remember that people use stances "at particular times when contemplating and developing particular text-worlds for themselves, and are meaningful only in the collective ideas they allow a person to gather" (Langer, 2011, p. 24). People do not, and indeed, according to Langer, should not "call upon the stances with equal frequency" (Langer, 2011, p. 24). The reason that Langer (and I) separate the stances is that they allow us to think about different ways of introducing and holding dialogues with students, thereby helping them to clarify and extend their understanding of the text. This makes them a useful analytical tool as they can help students define their level of understanding and response to the literary text. The reading logs and the dialogues that may result can help teachers to ask thought-provoking questions about literature, thereby enabling students to ponder and share their growing understanding and appreciation of what literature is and, not least, to see its potential advantages in the classroom.

\section{Overall results for all three groups of chapters}

Figure 1 below displays the results for the three groups of chapters: 1-5, 6-11 and 12-17. Separate tables showing the results for each chapter group are to be found in the appendix. It should be noted that it was impossible to divide the number of chapters completely evenly; the first group of chapters contains one less chapter than the remaining two groups.

Each column shows the number of each stance in each chapter group. The left axis is the number of stances. The different colours indicate the three different groups of chapters. 


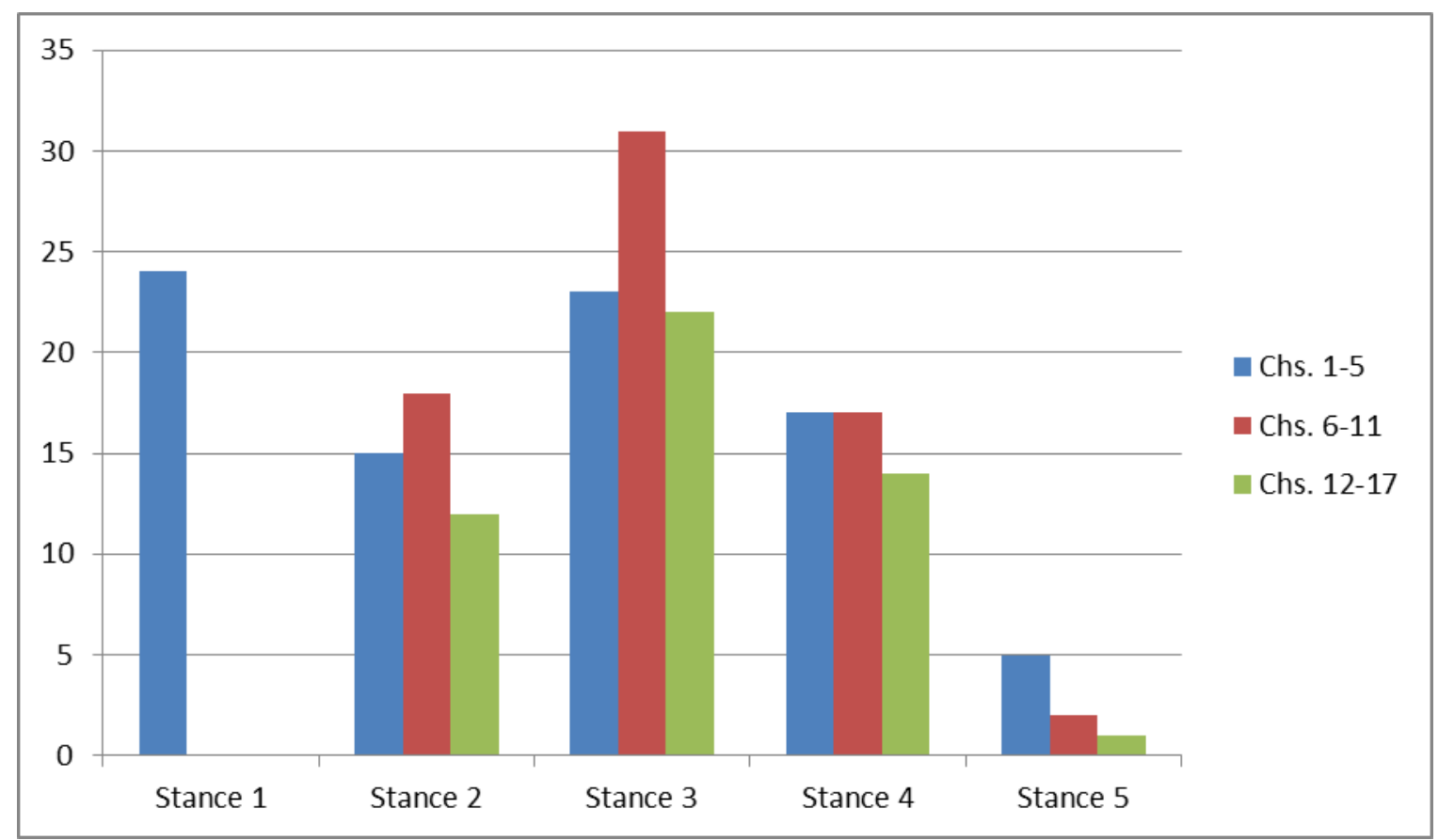

Figure 1. Overall results for all three groups of chapters in Harry Potter and the Philosopher's Stone

\section{Findings by incidence of stances}

\section{Stance one}

As already established, any highlighted examples of stances in the students' logbooks that could be conceived of as ambiguous and/or incomplete were ultimately removed from the entries discussed here. Ambiguity was not, however, a significant problem and where it occurred, it was due primarily to sloppy language. A case in point is the following: "I enjoyed reading Harry Potter because I've read quite alot about him and also read several of the novels" (student three; log book three). How much is "quite a lot", and what has he/she read? And how has this influenced his/her understanding of the novel? At first sight, such a comment implies deep reading as there is a connection to other texts but the lack of detail makes it impossible to classify the comment in terms of Langer's stances.

As the above figure demonstrates, the highest incidence of stance one (being outside and stepping into an envisionment) is to be found in the first five chapters. This is not surprising as the students are outside an envisionment; they are at the stage of picking up clues and making sense of them on the basis of "the little [they] already know" (Langer, 2011, p. 17). The reading of the novel has only just begun and students often notice only surface features of the text. They "form initial ideas and suppositions based on characters, plot, setting, situation - and how they interrelate" (Langer, 2011, p. 17). An example of a typical stance one comment is to be found in logbook ten: "I like this chapter 
[one], because it raises many questions that I want to figure out." Student fourteen writes about the first chapter as follows: "I hope and believe that J. K. Rowling invented the Dursley family to make other people more cautious and aware of their behavior in encounter with other people. Some people might see themselves in Mr. Dursley, and then make a change in their behavior for the better. I wonder what will happen to Harry in the next chapter.” The student has made a supposition about the character and the situation but, as would be the case in stance two, does not ask questions about "motives, feelings, causes, interrelationships, and implications” (Langer, 2011, p. 18).

\section{Stances two and three}

Stance two (being inside and moving through an envisionment) and stance three (stepping out and rethinking what you know) are most common in chapters 611. That stance two is common in chapters 6-11 is not surprising given that it is at this stage that we become immersed inside our text worlds, having moved beyond the introductory chapters. At this stage, readers are caught up in the narrative of the story. It becomes possible to make connections between our thoughts and our understanding of the text as part of the process of modifying our emerging sense of what the text is about. The author of logbook eight, for example, records: "I love how the book starts with Mr. and Mrs. Dursley that is perfectly normal, thank you very much. Every time I read that line I tend to laugh because they are so far from normal than you can get in my opinion, even Harry with his powers is more normal.”

Stance three (stepping out and rethinking what you know) is also common in chapters 6-11. As already established, stance three is different to the previous two as we do not use our knowledge and experience to make sense of the text but the other way round: our text worlds add to our own knowledge and experience. Stance three is relatively evenly distributed between the seventeen chapters, though there is a higher incidence in chapters 6-11. It is reasonable to suppose that the middle section of a text is the time when we are most likely to "shift the focus of meaning development for a moment, moving from the textworld that we are creating to what those ideas mean for our own lives, ideas, or knowledge" (Langer, 2011, p. 19). This is the time for stepping back and rethinking.

Following is an example of a typical stance three comment:

Like last chapter, the boys' excitement to try all the candy is relatable. In Hogsmeade, I tried some Every-Flavour Beans, Butterbeer and a Chocolate Frog. In it was a card of Helga Hufflepuff, founder of the house that everyone seems to make fun of, but since I like them I did not mind. Also, during my last placement period, I had the opportunity to teach Harry Potter and the Philosopher's Stone. One activity was group work with questions related to the objects I had brought with me, including a wand, a 
"Philosopher's" stone and candy. The pupils were especially excited when they got to try some beans, though not all were pleased with the flavour. Not surprisingly, this particular lesson is one of my personal favourites (logbook nine).

Here the student is clearly "moving from the text world that [he/she] is creating to what those ideas mean for [his/her] own [life], ideas, or knowledge" (Langer, 2011, p. 19).

As Langer notes, it is usually the case that stance three is less frequent than stances one, two and four. This is partly because not all texts intersect our lives in such a way that we can reflect on them. Langer also suggests that "it may take time and cumulative literary experiences before works start to have an impact on us” (2011, p. 19). In the case of Harry Potter and the Philosopher's Stone, the students are able to relate to the school situation described in the novel because they have learned about the British system of education. Because they are preservice teachers, they are able to compare what they are learning in education and pedagogy classes with what they read about Hogwarts School. Such comments allow students to re-think their vision of a "good" education, as well as what constitutes a "good" relationship between teacher and pupil. Langer emphasises that stance three is one of the most important reasons for reading and studying literature as it allows us "to sort out our own lives" (2011, p. 20).

\section{Stance four}

Stance four (stepping out and objectifying the experience) is equally common in chapters 1-5 and 6-11. This reflective and analytical stance relies on the ability of the reader to objectify his/her understanding of the text by focusing on literary elements. The ability to identify tensions between the world of the text and our own world, and to analyse conflicts and the representation of power, allows the reader to see the text and meaning from a distance. An example of this process is to be found in logbook 20, where the student writes:

Foreshadowing events is a technique that the narrator use throughout the book. For example, on page 16, McGonagall take notice of the scar left on Harry's forehead by Voldemort. Dumbledore states that he would not do anything about it even if he could because, "Scars can come in useful". This turns out to be true.

In the earlier mentioned introductory course on literary analysis, the students learned about the structure of the text, narratorial perspective, and how to identify and interpret literary elements. Their teacher training programme encourages them to objectify their experience with a view to applying it to their future career. In the above quotation, the student demonstrates some knowledge of literary analysis as he/she notes the narrator's use of foreshadowing. It is 
likely that this student will point out this technique in his/her classroom now that he/she is aware of it and its importance in terms of literary understanding.

\section{Stance five}

The highest incidence of stance five (leaving an envisionment and going beyond) is to be found in chapters 1-5. This is at first sight puzzling because the stance represents "rich and well-developed envisionments" (Langer, 2011, p. 21 ), which can be used in new and unrelated situations; these develop as the reader moves into the story. However, as the following example demonstrates, the two students (logbooks 20 and 21) who make the most frequent stance-five comments in the first eleven chapters rely on an earlier reading of the novel. This enables them to notice additional features that were missed in the first reading and make comparisons between their first and second reading.

The relative infrequency of stance five is in accordance with Langer's envisionment theory. Because it necessitates "moving away from our envisionments, often moving into an entirely new envisionment" (Langer, 2011, p. 21), it represents an advanced stage of reading. Six of the eight stance-five comments are made by the same student (logbook 21).

In relation to chapter three, for example, the student writes:

When reading this book I tend to compare it to the film, probably because the films about Harry Potter came out when I was still young and the visuals rather stuck in my head more than my own imagination. Because of this, the book gives me so much more in term of details and additional events that the film did not cover, like Uncle Vernon's mad trip. It is not my favourite chapter so far, because I would have liked to read the letter already and have Harry enter the magical world, but I will have to be patient...

The student is able to compare the film and book version of Harry Potter and the Philosopher's Stone and identify differences. He/she also reflects on how his age influences what he understands in a narrative.

While the advantages of having read the novel earlier and seen the film are clear, it is more difficult to explain why the author of logbook 21 makes relatively few stance-five comments in the remaining chapters (one stance-five comment in chs. 6-11; and one in chs. 12-17). This suggests that the initial advantages of having read the text before have become neutralised, or perhaps that the student is no longer comparing earlier observations with present ones, at least in terms of the novel Harry Potter and the Philosopher's Stone. Instead, something much more sophisticated has taken place by the later chapters, as indicated in the following observation: 
Since this is not my first time reading the Harry Potter book series, it is with great delight that I get to revisit some of the scenes that to my surprise are packed with tiny future references. How Hagrid borrowed the magical motorbike from Sirius Black, this story is explained in more detail in Harry Potter and the Prisoner of Azkaban. The mention of Dedalus Diggle, the Order of the Phoenix member that is tasked with keeping the Dursleys safe in Harry Potter and the Deathly Hallows. Also Dumbledore's fascination with sherbet lemon and other sweets, and his deluminator.

The author of logbook 21 is now able to keep a distance between the novel he/she is studying and relate his/her responses to later novels in the series. $\mathrm{He} / \mathrm{she}$ now understands references in the first novel in a new light and has thus moved into a new envisionment, which is characteristic of stance five.

And by chapter five, the same student recognises that he/she has become an "observant reader", as indicated in the following:

While reading the book list for Hogwarts and other books in the Harry Potter universe, the more observant readers may notice that the names of the authors are often somehow connected to the subject they write about. E.g.

- Magical Theory by Adalbert Waffling, meaning to speak in a deliberately questionable way.

- A Beginner's Guide to Transfiguration by Emeric Switch, Switch as in exchanging an item with another.

- One Thousand Magical Herbs and Fungi by Phyllinda Spore, spores are a part of fungus, and Phyllis is Greek for foliage.

- Magical Drafts and Poisons by Arsenius Jigger, Arsenius most likely derived from Arsenic, a poisonous chemical element.

- Curses and Counter-Curses by Professor Vindictus Viridian, Vindictus most likely derived from vindictive, meaning to be vengeful or inclined to seek revenge.

The author of logbook 21 is not only an observant but also highly perceptive reader! Most important of all, he/she has experienced the joys of being able to move outside the work and see new things in it.

The above examples demonstrate that stance one occurs most often in the early chapters, $1-5$. This is because the reader is forming and re-forming his/her expectations of the content of the text. Stance two occurs relatively evenly over all seventeen chapters. This is not unusual, because it is at this stage that the reader is orienting herself/himself to the text; this orientation can be adjusted as the reading process continues. Stance three is also relatively evenly distributed over all three chapters. Again, this is not unexpected as it is at this stage that the reader uses his/her own experience to interpret the text.

Like stances two and three, stance four is relatively evenly distributed over the chapters, with a slightly lower incidence in the final chapters, 12-17. Given that a reader with a knowledge of literary analysis will use this from the beginning, the findings for stance four are not unexpected. Also, the slightly 
lower incidence of this stance in the final chapters can possibly be explained by a) several examples of literary devices have already been given in the log; and b) the reader is anxious to know the outcome of the story and perhaps less inclined at this stage to note literary devices. This does not mean, however, that he/she has not noticed them.

Finally, it is stance five that constitutes the greatest surprise in the study. As already noted, it is unusual for readers to reach the level of literary understanding required at stance five level. It is necessary, however, to note that it is the same two students who reach this level. It is important for the students to recognise that they have reached a high level of reading as it gives encouragement. I talked to the two students about this after class; they were surprised because they had taken it for granted that a reader should be proficient in literary analysis and able to relate a text to other texts.

\section{Conclusion}

Teachers of pre-service students must experiment with new methods, adapt to changing learning and reading practices, and take note of new and exciting developments in research. It is, of course, not only pre-service students who need to learn but also their teachers. The results of my study suggest that introducing Langer's five reading stances into the classroom, and encouraging students to compile reading logs that they discuss with their fellow students, has the potential to produce not only deeper and more self-critical readers but also teachers who can encourage the development of such qualities in their pupils.

Identifying stances in reading logs promotes self-awareness, self-regulated learning (including self-diagnosis), literate thinking, and envisionment building, all of which not only enrich the student's reading but also his/her teaching. Teachers will be equipped to pass on sound reading practices that will give pleasure as well as promote critical reading and thinking among their pupils.

My research has given me insight into students' reading processes. In order to expand my project I wish to create opportunities for the students themselves to analyse the various stances in their own and their fellow-students' logs, enabling them to work with their metacognitive skills.

It is my intention to develop the present project in the autumn term 2017, with a corresponding group of pre-service students training to teach levels 1-7 and 5-10 in the Norwegian system. This time, however, the text will be Lois Lowry's The Giver (1993), which has replaced Harry Potter and the Philosopher's Stone in the syllabus. In the new project, students will be given more time to discuss one another's comments in class. They will categorise their comments as they discuss their logs in the first four sessions of the course. In this way, their learning will become self-regulative in the sense understood by Flavell (1985) and discussed above. When the logbooks are complete, i.e. by the 
final seminar on The Giver, the students will be asked to study their comments in terms of Langer's five stances. These will be presented in the same session and discussed.

To conclude, my study demonstrates that with a heightened awareness of the different levels at which people read texts, it is possible to develop a richer awareness of how we read and understand literature. Compiling reading logs and assessing observations with the aid of Langer's reading stances also provide teachers with important insights into their students' depth of reading. My follow-up study will extend these advantages to the student teachers themselves. Langer's envisionment theory and its application in reading logs has enormous potential for teacher trainers and student teachers alike.

\section{About the author}

Jane Mattisson Ekstam is Professor of English at Østfold University College Institutional affiliation: The Faculty of Business, Languages, and Social Sciences, Østfold University College, P.O. Box 700, NO-1757 Halden, Norway E-mail: jane.m.ekstam@hiof.no

\section{References}

Aebersold, A. J. \& Field, M. L. (1997). From Reader to Reading Teacher: Issues and Strategies for Second Language Classrooms. Cambridge: Cambridge University Press.

Alexander, P. A. \& Jetton, T. L. (2000). Learning from text: A multidimensional and developmental perspective. In M. L. Kamil, P. B. Mosenthal, P. D. Pearson \& R. Barr (Eds.), Handbook of reading research 3, (285-310). Mahwah, NJ: Erlbaum.

Alsup, J. (2006). Teacher identity discourses: Negotiating personal and professional spaces. Mahwah, NJ: Lawrence Erlbaum.

Amer, A. A. (2003). Teaching EFL/ESL Literature. The Reading Matrix 3(2), 69-70.

Barclay, J. (1996). Learning from experience with learning logs. The Journal of Management Development 15(6), 28-43.

Bauso, J. A. (1988). Incorporating Reading Logs. Teaching English in the two-year college 15(4), 255-261.

Bazerman, C. (1985). Physicist reading physics: Schema-laden purposes and purpose-laden schema. Written Communication 2(1), 3-23.

Belcher, C. L. \& Stephenson, B. H. (2011). Teaching Harry Potter. The Power of Imagination in Multicultural Classrooms. New York: Palgrave Macmillan.

Benton, M. and Fox, G. (1985). Teaching Literature: Nine to Fourteen (Oxford Studies in Education). Oxford: Oxford University Press.

Bruner, J. S. (1990). Acts of Meaning. Harvard: Harvard University Press.

Carlisle, A. (2000). Reading logs: an application of reader-response theory in ELT. ELT Journal 54(1), 12-18.

Carrell, P. L., Devine, J. \& Eskey, D. E. (1988). Interactive Approaches to Second Language Learning. Cambridge University Press. 
Corbett, P. (2003). How to Teach Story Writing at Key Stage 1. Abingdon: David Fulton.

Darling-Hammond, L., Bransford, J., LePage, P., Hammerness, K. \& Duffy, H. (2007). Preparing Teachers for a Changing World: What Teachers Should Learn and Be Able to Do. San Francisco, CA: Jossey-Bass.

Duff, A. \& Maley, A. (1990). Literature (Resource Book for Teachers). Oxford: Oxford University Press.

Duffy, G. G. (2005). Developing Metacognitive Teachers: Visioning and the Expert's Changing Role in Teacher Education and Professional Development. In S. E. Israel, C. C. Block, K. L. Bauserman \& K. Kunnucan-Welsch (Eds.), Metacognition in Literacy Learning. Theory, Assessment, Instruction, and Professional Development (pp. 299-313). Mahwah, NJ: Lawrence Erlbaum Associates.

Eskey, D. E. and Grabe, W. (1988). Interactive Models for Second Language Reading: Perspectives on Instruction, in Carrell, P. L., Devine, J. and Eskey, D. E. (eds) (1988) Interactive Approaches to Second Language Reading. Cambridge: Cambridge University Press.

Flavell, J. H. (1985). Cognitive Development (2nd ed.). Englewood Cliffs, NJ: Prentice-Hall. Gambrell, M. \& Morrow, L. M. (Eds.), (2015). Best Practices in Literary Instruction. Guildford: Guildford Press.

Griffith, P. L. \& Ruan, J. (2005). What Is Metacognition and What Should be Its Role in Literacy Instruction? In S. E. Israel., et al. Metacognition in Literacy Learning. Theory, Assessment, Instruction, and Professional Development (pp. 3-18). New York and London: Routledge.

Hiemstra, R. (2001). Uses and Benefits of Journal Writing. Promoting Journal Writing in Education, 2001(90), 19-26.

Kern, E. M. (2003). The Wisdom of Harry Potter. What Our Favourite Hero Teaches Us about Moral Choices. New York: Prometheus Books.

Kjelen, H. A. (2013). Litteraturundervisning i ungdomsskolen: Kanon, danning og kompetanse (The teaching of literature in the lower secondary school: Canon, bildung and competence). Unpublished doctoral dissertation. Norwegian University of Science and Technology (NTNU), Trondheim, Norway.

Krogh, E., Penne, S. \& Ulfgard, M. (2012). Oppsummering. Den nordiske skolen - Finns den? (The Nordic school - Does it exist?). In N. Frydensbjerg Elf \& P. Kaspersen (Eds.). Den nordiske skolen - finns den? Didaktiske diskurser og dilemmaer i skandinaviske morsmålsfag (The Nordic school - Does it exist? Didactical discourses and dilemmas in Scandinavian mother tongue subjects) (pp. 244-258). Oslo, Norway: Novus Förlag.

Langer, J. (2011). Literary Understanding and Literature Instruction. (2nd ed.). New York \& London: Teachers College.

Langer, J. https://www.youtube.com/watch?v=GtI2rRfPy7o. Accessed 21 March 2018.

Lowry, L. (1993). The Giver. Boston: Houghton Mifflin.

Lyutaya, T. (2011). Reading Logs: Integrating Extensive Reading with Writing Tasks. English Teaching Forum 1, 26-34.

McDaniel, C. (2004). Critical Literacy: A questioning stance and the possibility for change. The Reading Teacher, 57(5), 472-481.

McKenna, M. C. \& Dougherty Stahl, K. A. (2015). Assessment for Reading Instruction. Guildford: Guildford Press.

McRae, J. (1991). Literature with a Small "I”. London: Macmillan.

Montgomery, M., Durant, A., Fabb, N., Furniss, T. \& Mills, S. (2000). Ways of Reading: Advanced Reading Skills for Students of English Literature. London: Routledge. 
Pressley, M. (2000). What should comprehension instruction be the instruction of? In M. L. Kamil, P. B. Mosenthal, P. D. Pearson \& R. Barr (Eds.), Handbook of reading research: Volume III. Mahwah, NJ: Erlbaum.

Pressley, M., Brown, R., El-Dinary, P. \& Afflerbach, P. (1995). The comprehension instruction that students need: Instruction fostering constructively responsive reading. Learning Disabilities Research \& Practice, 10(4), 215-224.

Reyes, M. de la Ruz. (1991). A Process Approach to Literacy Using Dialogue Journals and Literature Logs with Second Language Learners. Research in the Teaching of English 25(3), 29l-313.

Rosenblatt, L. M. (1983). Literature as Exploration. New York: Barnes \& Noble.

Rowling, J. K. (2017). Harry Potter and the Philosopher's Stone. London: Bloomsbury children's books. First published in 1997.

Rødnes, K. A. (2014). Skjønnlitteratur i klassrommet: Skandinaviske forskning och didaktiske implikasjoner (Literature in the classroom: Scandinavian research and didactical implications). Acta Didactica Norge 8(1), 1-17.

Skarstein, D. (2013). Meningsdannelse og diversitet: En didaktiskt undersøkelse av elevers lesninger av norskfagets litterære teskster (Meaning making and diversity: A didactical investigation of literary texts in the Norwegian classroom). Unpublished doctoral dissertation. University of Bergen, Bergen, Norway.

Smyth, J. (1989). A “pedagogical” and “educative” view of leadership. In J. Smyth (Ed.),

Critical perspectives on educational leadership (pp. 179-204). London: Falmer.

Spolsky, B. (1989). Conditions for Second Language Learning: Introduction to a General Theory (Language Education). Oxford: Oxford University Press.

Tolkien, J. R. R. (1997). On Fairy-Stories. In C. Tolkien (Ed.), The Monsters and the Critics and other essays. London: HarperCollins.

Wallace, C. (1992). Reading: A Scheme for Education. Oxford: Oxford University Press.

Wilson, N. (1989). Learning from Confusion: Questions and Change in Reading Logs. The English Journal, 78(7), 62-69. 


\section{Appendix}

Table 1. Stances 1-5. Chapters 1-5 (Harry Potter and the Philosopher's Stone)

\begin{tabular}{|c|c|c|c|c|c|c|}
\hline Student & Stance 1 & Stance 2 & Stance 3 & Stance 4 & Stance 5 & TOTAL \\
\hline 1 & 5 & 0 & 0 & 0 & 0 & Stance 1: 5 \\
\hline 2 & 2 & 0 & 3 & 2 & 0 & $\begin{array}{l}\text { Stance1: } 2 \\
\text { Stance 3: } 1 \\
\text { Stance 4: } 2\end{array}$ \\
\hline 3 & 0 & 0 & 0 & 0 & 0 & $\begin{array}{l}\text { There are no Reader Response } \\
\text { comments in this log }\end{array}$ \\
\hline 4 & 1 & 1 & 0 & 2 & 0 & $\begin{array}{l}\text { Stance 1: } 1 \\
\text { Stance 2: } 1 \\
\text { Stance 4: } 2\end{array}$ \\
\hline 5 & 5 & 0 & 0 & 0 & 0 & Stance 1: 5 \\
\hline 6 & 0 & 0 & 2 & 0 & 0 & Stance 3: 2 \\
\hline 7 & 0 & 0 & 0 & 0 & 0 & $\begin{array}{l}\text { There are no Reader Response } \\
\text { comments in this log }\end{array}$ \\
\hline 8 & 0 & 1 & 4 & 0 & 0 & $\begin{array}{l}\text { Stance 2: } 1 \\
\text { Stance 3: } 4\end{array}$ \\
\hline 9 & 0 & 0 & 1 & 4 & 0 & $\begin{array}{l}\text { Stance 3:1 } \\
\text { Stance 4: } 4\end{array}$ \\
\hline 10 & 2 & 0 & 1 & 0 & 0 & $\begin{array}{l}\text { Stance 1: } 2 \\
\text { Stance 3: } 1\end{array}$ \\
\hline 11 & 2 & 1 & 0 & 0 & 0 & $\begin{array}{l}\text { Stance 1: } 2 \\
\text { Stance 2: } 1\end{array}$ \\
\hline 12 & 1 & 1 & 1 & 0 & 0 & $\begin{array}{l}\text { Stance 1: } 1 \\
\text { Stance 2: } 1 \\
\text { Stance 3: } 1\end{array}$ \\
\hline 13 & 0 & 0 & 2 & 0 & 0 & Stance 3: 2 \\
\hline 14 & 1 & 2 & 0 & 0 & 0 & $\begin{array}{l}\text { Stance 1: } 1 \\
\text { Stance 2: } 2\end{array}$ \\
\hline 15 & 1 & 1 & 1 & 0 & 0 & $\begin{array}{l}\text { Stance 1: } 1 \\
\text { Stance 2: } 1 \\
\text { Stance 3: } 1 \\
\end{array}$ \\
\hline 16 & 1 & 2 & 3 & 0 & 0 & $\begin{array}{l}\text { Stance 1: } 1 \\
\text { Stance 2: } 1 \\
\text { Stance 3: } 1\end{array}$ \\
\hline 17 & 1 & 0 & 0 & 0 & 0 & Stance 1: 1 \\
\hline 18 & & & & & & $\begin{array}{l}\text { There are no Reader Response } \\
\text { comments in this log }\end{array}$ \\
\hline 19 & 1 & 3 & 2 & 5 & 0 & $\begin{array}{l}\text { Stance 1: } 1 \\
\text { Stance 2: } 3 \\
\text { Stance 3: } 2 \\
\text { Stance 4: } 5 \\
\end{array}$ \\
\hline 20 & 1 & 2 & 2 & 4 & 1 & $\begin{array}{l}\text { Stance 1: } 1 \\
\text { Stance 2: } 2 \\
\text { Stance 3: } 2 \\
\text { Stance 4:4 } \\
\text { Stance 5: } 1\end{array}$ \\
\hline 21 & 0 & 0 & 0 & 0 & 4 & Stance 5: 4 \\
\hline 22 & 0 & 1 & 1 & 0 & 0 & $\begin{array}{l}\text { Stance 2: } 1 \\
\text { Stance 3: } 1\end{array}$ \\
\hline TOTAL & 24 & 15 & 23 & 17 & 5 & \\
\hline
\end{tabular}


Table 2. Stances 1-5. Chapters 6-11 (Harry Potter and the Philosopher's Stone)

\begin{tabular}{|c|c|c|c|c|c|c|}
\hline Student & Stance 1 & Stance 2 & Stance 3 & Stance 4 & Stance 5 & TOTAL \\
\hline 1 & 0 & 5 & 2 & 0 & 0 & $\begin{array}{l}\text { Stance 2: } 5 \\
\text { Stance 3: } 2\end{array}$ \\
\hline 2 & 0 & 0 & 3 & 0 & 0 & Stance 3: 3 \\
\hline 3 & & & & & & $\begin{array}{l}\text { There are no Reader Response } \\
\text { comments in this log }\end{array}$ \\
\hline 4 & 0 & 0 & 1 & 2 & 0 & $\begin{array}{l}\text { Stance 3: } 1 \\
\text { Stance 4: } 2\end{array}$ \\
\hline 5 & 0 & 1 & 2 & 0 & 0 & $\begin{array}{l}\text { Stance 2: } 1 \\
\text { Stance 3: } 2\end{array}$ \\
\hline 6 & 0 & 0 & 2 & 1 & 0 & $\begin{array}{l}\text { Stance 3: } 2 \\
\text { Stance 4: } 1\end{array}$ \\
\hline 7 & 0 & 0 & 0 & 0 & 0 & $\begin{array}{l}\text { There are no Reader Response } \\
\text { comments in this log }\end{array}$ \\
\hline 8 & 0 & 0 & 0 & 2 & 0 & Stance $4: 2$ \\
\hline 9 & 0 & 0 & 0 & 2 & 0 & Stance 4: 2 \\
\hline 10 & 0 & 2 & 2 & 0 & 0 & $\begin{array}{l}\text { Stance 2: } 2 \\
\text { Stance 3: } 2\end{array}$ \\
\hline 11 & 0 & 2 & 0 & 0 & 0 & Stance 2: 2 \\
\hline 12 & 0 & 1 & 3 & 0 & 0 & $\begin{array}{l}\text { Stance 2: } 1 \\
\text { Stance 3: } 3\end{array}$ \\
\hline 13 & 0 & 1 & 3 & 0 & 0 & $\begin{array}{l}\text { Stance 2: } 1 \\
\text { Stance 3: } 3\end{array}$ \\
\hline 14 & 0 & 2 & 2 & 0 & 0 & $\begin{array}{l}\text { Stance 2: } 2 \\
\text { Stance 3: } 2\end{array}$ \\
\hline 15 & 0 & 1 & 1 & 1 & 0 & $\begin{array}{l}\text { Stance 2: } 1 \\
\text { Stance 3: } 1 \\
\text { Stance 4: } 1\end{array}$ \\
\hline 16 & 0 & 1 & 1 & 0 & 0 & $\begin{array}{l}\text { Stance 2: } 1 \\
\text { Stance 3: } 1\end{array}$ \\
\hline 17 & 0 & 0 & 1 & 1 & 0 & $\begin{array}{l}\text { Stance 3: } 1 \\
\text { Stance 4: } 1\end{array}$ \\
\hline 18 & 0 & 0 & 0 & 0 & 0 & $\begin{array}{l}\text { There are no Reader Response } \\
\text { comments in this log }\end{array}$ \\
\hline 19 & 0 & 0 & 3 & 4 & & $\begin{array}{l}\text { Stance 3: } 3 \\
\text { Stance 4: } 4\end{array}$ \\
\hline 20 & 0 & 2 & 3 & 4 & 1 & $\begin{array}{l}\text { Stance 2: } 2 \\
\text { Stance 3: } 3 \\
\text { Stance 4: } 4 \\
\text { Stance 5: } 1\end{array}$ \\
\hline 21 & 0 & 0 & 0 & 0 & 1 & Stance 5: 1 \\
\hline 22 & 0 & 0 & 2 & 0 & 0 & Stance 3: 2 \\
\hline TOTAL & 0 & 18 & 31 & 17 & 2 & \\
\hline
\end{tabular}


Table 3. Stances 1-5. Chapters 12-17 (Harry Potter and the Philosopher's Stone)

\begin{tabular}{|c|c|c|c|c|c|c|}
\hline Student & $\begin{array}{l}\text { Stance } \\
1\end{array}$ & $\begin{array}{l}\text { Stance } \\
2\end{array}$ & $\begin{array}{l}\text { Stance } \\
3\end{array}$ & $\begin{array}{l}\text { Stance } \\
4\end{array}$ & $\begin{array}{l}\text { Stance } \\
5\end{array}$ & TOTAL \\
\hline 1 & 0 & 5 & 2 & 0 & 0 & $\begin{array}{l}\text { Stance 2: } 5 \\
\text { Stance 3: } 2\end{array}$ \\
\hline 2 & 0 & 0 & 1 & 1 & 0 & $\begin{array}{l}\text { Stance 3:1 } \\
\text { Stance 4: } 1\end{array}$ \\
\hline 3 & 0 & 0 & 0 & 0 & 0 & $\begin{array}{l}\text { There are no Reader Response } \\
\text { comments in this log }\end{array}$ \\
\hline 4 & 0 & 0 & 1 & 2 & 0 & $\begin{array}{l}\text { Stance 3: } 1 \\
\text { Stance 4: } 2\end{array}$ \\
\hline 5 & 0 & 0 & 0 & 0 & 0 & $\begin{array}{l}\text { Student gives up making Reader Response } \\
\text { comments: "It's exciting and nerve wracking, } \\
\text { but I'm so tired of this task that I cannot think } \\
\text { of anything good about this chapter or book } \\
\text { at this point. It is a pity that task destroys the } \\
\text { pleasurable reading of the book and the } \\
\text { excitement because you are so tired. That is } \\
\text { how I feel about it, and I am not going to } \\
\text { hide it." }\end{array}$ \\
\hline 6 & 0 & 0 & 0 & 1 & 0 & Stance 4: 1 \\
\hline 7 & & & & & & $\begin{array}{l}\text { There are no Reader Response } \\
\text { comments in this log }\end{array}$ \\
\hline 8 & 0 & 0 & 2 & 0 & 0 & Stance 3: 2 \\
\hline 9 & 0 & 0 & 1 & 2 & 0 & $\begin{array}{l}\text { Stannce 3: } 1 \\
\text { Stance 4: } 2\end{array}$ \\
\hline 10 & 0 & 3 & 1 & 0 & 0 & $\begin{array}{l}\text { Stance 2: } 3 \\
\text { Stance 3: } 1\end{array}$ \\
\hline 11 & 0 & 0 & 3 & 0 & 0 & Stance 3: 3 \\
\hline 12 & 0 & 0 & 2 & 0 & 0 & Stance 3: 2 \\
\hline 13 & 0 & 0 & 2 & 0 & 0 & Stance 3: 2 \\
\hline 14 & 0 & 0 & 1 & 0 & 0 & Stance 3: 1 \\
\hline 15 & 0 & 0 & 1 & 1 & & $\begin{array}{l}\text { Stance 3: } 1 \\
\text { Stance 4: } 1\end{array}$ \\
\hline 16 & 0 & 2 & 1 & 0 & 0 & $\begin{array}{l}\text { Stance 2: } 2 \\
\text { Stance 3: } 1\end{array}$ \\
\hline 17 & 0 & 0 & 1 & 0 & 0 & Stance 3: 1 \\
\hline 18 & 0 & 0 & 0 & 0 & 0 & $\begin{array}{l}\text { There are no Reader Response } \\
\text { comments in this log }\end{array}$ \\
\hline 19 & 0 & 0 & 0 & 3 & 0 & Stance 4: 3 \\
\hline 20 & 0 & 0 & 0 & 3 & 0 & Stance 4: 3 \\
\hline 21 & 0 & 0 & 0 & 0 & 1 & Stance 5: 1 \\
\hline 22 & 0 & 0 & 0 & 1 & 0 & Stance 4: 1 \\
\hline TOTAL & 0 & 12 & 22 & 14 & 1 & \\
\hline
\end{tabular}


Table 4. Stances 1-5. Overall results for all seventeen chapters of Harry Potter and the Philosopher's Stone

\begin{tabular}{|c|c|c|c|c|c|}
\hline Student & Stance 1 & Stance 2 & Stance 3 & Stance 4 & Stance 5 \\
\hline 1 & 5 & 10 & 2 & 0 & 0 \\
\hline 2 & 2 & 0 & 7 & 3 & 0 \\
\hline 3 & 0 & 0 & 0 & 0 & $\begin{array}{l}\text { There are no Reader Response } \\
\text { comments in this log }\end{array}$ \\
\hline 4 & 1 & 1 & 2 & 6 & 0 \\
\hline 5 & 5 & 1 & 2 & 0 & 0 \\
\hline 6 & 0 & 0 & 4 & 2 & 0 \\
\hline 7 & 0 & 0 & 0 & 0 & $\begin{array}{l}\text { There are no Reader Response } \\
\text { comments in this log }\end{array}$ \\
\hline 8 & 0 & 1 & 6 & 2 & 0 \\
\hline 9 & 0 & 0 & 2 & 8 & 0 \\
\hline 10 & 2 & 5 & 4 & 0 & 0 \\
\hline 11 & 2 & 3 & 3 & 0 & 0 \\
\hline 12 & 1 & 2 & 6 & 0 & 0 \\
\hline 13 & 0 & 1 & 7 & 0 & 0 \\
\hline 14 & 1 & 4 & 3 & 0 & 0 \\
\hline 15 & 1 & 2 & 3 & 2 & 0 \\
\hline 16 & 1 & 4 & 3 & 0 & 0 \\
\hline 17 & 1 & 0 & 2 & 1 & 0 \\
\hline 18 & 0 & 0 & 0 & 0 & $\begin{array}{l}\text { There are no Reader Response } \\
\text { comments in this log }\end{array}$ \\
\hline 19 & 1 & 3 & 5 & 12 & \\
\hline 20 & 1 & 4 & 5 & 11 & 2 \\
\hline 21 & 0 & 0 & 0 & 0 & 6 \\
\hline 22 & 0 & 1 & 3 & 1 & 0 \\
\hline TOTAL & 24 & 42 & 69 & 48 & 8 \\
\hline
\end{tabular}




\section{READING LOG INSTRUCTIONS ON FRONTER. ABBREVIATED FORM}

For this assignment, you are asked to try out a literary didactic method in your work with one of our novels, J. K. Rowling's Harry Potter and the Philosopher's Stone. I would like you to write a reading log that documents your thoughts and feelings in your encounter with the text.

On the next page, you will find a box of suggestions for what a reading log can contain. In this general description, taken from Aly A. Amer's article "Teaching EFL/ESL Literature" (see compendium) you are expected to write an entry for each chapter in the book.

When you are writing your log entries, it may be useful to do so in a small notebook and then write up the entries in Word for hand-in. In your small notebook, you can follow the headings outlined in Amer's article and then restructure these ideas in accordance with the three headings that I have identified: content, structure and style. If, however, you are a digital person, please feel free to write directly in a computer file for hand-in.

Please note:

You need to bring your logbook to class every week as you will be discussing your notes with your fellow students. You will work in a small group to do this. I ask you to leave a space if you are writing by hand (approximately half a page) so that you can fill in comments from your fellow students. It is, however, more convenient for all if your logbook is digital. You will also comment on the comments! For this part of your logbook, please use the following two headings: Student comments

My comments on my fellow students' comments

Please give each student in your group a number: do not write student names in your logbooks, please. You will keep to the same groups so please stay within your two main age groups: 1-7 and 5-10. 


\section{Reading Logs}

As you read the book write down all the things that go on in your head in a "stream of consciousness" style. As you read, you will be making a record of images, associations, feelings, thoughts, judgments, etc. You will probably find that this record will contain:

Questions that you ask yourself about characters and events as you read. (Answer these yourself when you can.

Memories from your own experience provoked by the reading.

Guesses about how you think the story will develop, and why.

Reflections on striking moments and ideas in the book.

Comparisons between how you behave and how the characters in the novel are behaving.

Thoughts and feelings about characters and events.

Comments on how the story is being told. For example, any words or phrases or even whole passages that make an impression on you, or motifs which you notice the author keeps using.

Connections to other texts, ideas and courses.

An outline of the chapter [or section], no longer than a paragraph.

Please date each entry, and note down the time and place, as well as the mood you are in while reading.

Please note down the page number you are reading when you make an entry.

From: Aly Anwar Amer. “Teaching EFL/ESL Literature”. The Reading Matrix. Vol. 3, No. 2, Sept. 2003, pp. 69-70. 